\title{
Analysis of Response Time and Quality of Professional Service Provider Care (PPA) with Patient Satisfaction in Hospital Poly Disease in Kartini Mojokerto
}

\author{
Langit Kresna Janitra ${ }^{1}$, Sandu \\ Siyoto $^{2}$, Rahmania Ambarika ${ }^{3}$ \\ ${ }^{1}$ Department of Health, \\ Mojokerto Regency, Indonesia \\ ${ }^{2}$ IIK STRADA Indonesia \\ ${ }^{3}$ IIK STRADA Indonesia \\ Email: \\ langitkresna99@gmail.com
}

Received: March $8^{\text {th }} 2021$

Accepted : April 12 2021

Published : May $20^{\text {th }} 2021$

\begin{abstract}
To create patient satisfaction, the hospital must create and manage a system to obtain more patients and the ability to retain patients. The process of patient care and care is dynamic and involves many Caregiver Professionals (PPA) and involves various service units. There are many problems regarding the lack of satisfaction from health care workers, one of which is due to the long response time. This study aims to analyze the relationship between response time and service quality of health workers with satisfaction of outpatients at Kartini Hospital, Mojokerto. This study used a quantitative analytic design with a cross sectional approach. The population was all unhospitalited patients who had received services the internal medicine poly at Kartini Hospital, Mojokerto with a total of 156 respondents. The sample used Simple Random Sampling totaling 112 respondents. Independent variables are response time and service quality. The dependent variable is outpatient satisfaction. Data analysis using Ordinal Regression. The time of the study was 18-23 March 2020. Based on the results of the Ordinal Regression Test analysis, it shows that the variable that most influences patient satisfaction is the variable service quality with a p-value of $0.013<0.05$, so $\mathrm{H} 0$ is rejected and $\mathrm{H} 1$ is accepted, so it can be concluded that there is a significant relationship between the quality of health care workers and satisfaction. On Outpatients at Kartini Hospital, Mojokerto Regency.
\end{abstract}

Keywords: Response time, service quality, patient satisfaction

Copyright ( 2021 IIK STRADA Indonesia All right reserved.

This is an open-acces article distributed under the terms of the Creative Commons Attribution-ShareAlike 4.0 International License.

\section{INTRODUCTION}

The process of patient care and care is dynamic and involves many Caregiver Professionals (PPA) and involves various service units. Integrase and coordination of service activities and patient care is a goal that results in efficiency, effective use and other resources and better patient care outcomes. Patient assessment of nurse services comes from patient experience. Aspects of patient experience can be interpreted as a treatment or action from nurses who are or have experienced, felt and borne by someone who uses nurse services (Jatmiko, 2013).

Educational factors affect work behavior, the higher education will be directly proportional to one's work behavior (Pangewa, 2007). Work behavior is a person's response or reaction that arises in 
the form of an act or attitude or someone's perception of his job (Maulana, 2013). The behavior in providing services is in line with the level of professional education of care givers (PPA) which is a higher education including doctors, nurses, midwives, pharmacists, analysts and nutritionists which can lead to significant changes in the way PPA provides care gradually and shift from the original orientation to the task of being goal-oriented focusing on providing effective patient care with a holistic approach and communication process to patients.

There are many problems regarding the lack of satisfaction from health care workers, one of which is due to the long response time. A number of phenomena are often encountered due to the large number of health workers' agendas, internal and external factors that cause officers to override the response time which should not be more than 60 minutes, patients have to wait a long time for the presence of these health workers starting from the waiting time spent in the administration to the the inspection queue must wait again. So that this causes the response time to be longer and affects the negative complaints about services in these health facilities (Indarto, 2010).

In addition to response time, there are also problems regarding the quality of health workers that are not in accordance with existing operational standards. Based on data from the Mojokerto District Health Office for the last three years, Kartini Hospital, which annually has decreased outpatient visits from 2015 to 2017, in 2015 the number of patient visits was 26,801 people, in 2016 23,173 people, 2017 as many as 26,801 people. 20,756 people (Dinkes Mojokerto, 2017). The decrease in the number of patient visits every year is due to two factors, namely satisfaction and services that allow the number of sick patient visits in the Kartini Hospital work area to decrease, whether services from Kartini Hospital have been provided to patients cause dissatisfaction and affect the quality of service provided and decrease in the number of patients (Kartini Hospital Medical Record, 2017).

Based on a preliminary study conducted by researchers on September 28, 2019 at the Kartini Hospital, Mojokerto Regency, out of 20 respondents data was collected. It is known that 15 respondents $(75 \%)$ said that the waiting time spent in one service is too long, around 60 minutes more and while getting service, health workers are less responsive to patient complaints so that patients are less satisfied with the services at the hospital. And 5 respondents $(25 \%)$ said that the waiting time spent in one service is not long where it is only less than 60 minutes, the officer is responsive to patient complaints and causes good satisfaction from patients to the health facility services.

Hospital is a functional health organization unit which is a center for community health development which also fosters community participation in addition to providing comprehensive and integrated services to the community in its working area in the form of main activities. In other words, the hospital has the authority and responsibility for maintaining public health in its working area (Satrianegara 2014).

Health services are an important factor in improving the health and welfare of every person around the world. According to Law No. 36 Article 19 of 2009 concerning health, explains that everyone has the right to obtain health services and the government is responsible for the availability of all forms of quality, safe, efficient and affordable health efforts by all levels of society. One of these efforts is to increase the availability and distribution of basic health facilities such as hospitals in each region (Bappenas, 2013).

Service quality can be identified by comparing consumers' perceptions of the service they receive with the service they actually expect for the service attributes of a company. Service quality is perceived as good and satisfying if the service received or perceived (perceived service) is as expected, if the service received exceeds consumer expectations, then the service quality is perceived to be very good and quality. The quality of service is perceived as bad if the service received is lower than expected (Amrizal, 2014). The quality of health services refers to the level of perfection in the appearance of health services that can satisfy every user of health services in accordance with the average level of satisfaction of the population, the procedures for its implementation are in accordance with established standards and professional code of ethics. 
According to the Indonesian Ministry of Health (2012), one of the indicators of service quality is the response time or what is called the Response Time. In 2009, the Minister of Health established one of the general principles regarding the handling of patients who had to be treated for a maximum of 60 (sixty) minutes starting from the time the patient came to register at the counter, queued and waited for a call to the polyclinic to be analyzed and examined by a doctor, nurse or midwife. The minimum standard of outpatient services based on the Ministry of Health Number 129 / Menkes / SK / II / 2008 is less or equal to 60 minutes (Ministry of Health, 2013).

Service quality can be identified by comparing consumers' perceptions of the service they receive with the service they actually expect for the service attributes of a company. Service quality is perceived as good and satisfying if the service received or perceived (perceived service) is as expected, if the service received exceeds consumer expectations, then the service quality is perceived to be very good and quality (Wijoyo, 2012).

Understanding the patient's needs and wants is an important thing that affects patient satisfaction. Satisfied patients are a very valuable asset because if patients are satisfied they will continue to use the services of their choice, but if patients are dissatisfied they will tell others twice as much about their bad experiences. To create patient satisfaction, the organization must create and manage a system to obtain more patients and the ability to retain patients.

\section{Research purposes}

In general, this study was conducted to analyze the relationship between response time and service quality of health workers with satisfaction of outpatients at Kartini Hospital, Mojokerto.

\section{METHOD}

This study used a quantitative analytic design with a cross sectional approach. The population is all outpatients who have received services at the Internal medicine poly Department of Kartini Hospital, Mojokerto with a total of 156 respondents. The sample used Simple Random Sampling totaled 112 respondents. Independent variables are response time and service quality. The dependent variable is outpatient satisfaction. Data analysis using Ordinal Regression. The time of the study was 18-23 March 2020.

\section{RESULTS}

Tabel 1. Respondent Characteristics

\begin{tabular}{lcc}
\hline Gender & Frequency & Percentage (\%) \\
\hline Man & 33 & 29 \\
Female & 79 & 71 \\
Long time sick & 30 & 27 \\
$<6$ months & 82 & 73 \\
$>6$ months & & \\
Type of disease & 44 & 39 \\
Hypertension & 27 & 24 \\
Diabetes & 19 & 17 \\
Stroke & 22 & 20 \\
Other diseases & & \\
Education & 34 & 30 \\
Junior high school & 75 & 67 \\
Senior high school & 3 & 3 \\
University & & \\
Respon time & 108 & 96,4 \\
Fast & & \\
\hline
\end{tabular}




\begin{tabular}{lcc}
\hline Slow & 4 & 3,6 \\
Service quality & & \\
Good & 89 & 79,5 \\
Enough & 21 & 18,8 \\
Less & 2 & 1,7 \\
Satisfaction & & \\
Satisfied & 106 & 94,6 \\
Not satisfied & 6 & 5,4 \\
\hline
\end{tabular}

Tabel 2. Results of the Ordinal Regression Test analysis

\begin{tabular}{|c|c|c|c|}
\hline & Value & df & Asymptotic Significance (2-sided) \\
\hline Pearson Chi-Square & $48.134^{\mathrm{a}}$ & 2 & .000 \\
\hline Likelihood Ratio & 26.343 & 2 & .000 \\
\hline Linear-by-Linear Association & 37.029 & 1 & .000 \\
\hline $\mathrm{N}$ of Valid Cases & 112 & & \\
\hline
\end{tabular}

Based on the results of the Ordinal Regression Test analysis, it shows that the variable that most influences patient satisfaction is the variable service quality with a p-value of 0.013 $<0.05$, so $\mathrm{H} 0$ is rejected and $\mathrm{H} 1$ is accepted, so it can be concluded that there is a significant relationship between the quality of health care workers and satisfaction. In Outpatients at the Internal Medicine Poly Kartini Hospital, Mojokerto Regency.

\section{DISCUSSION}

\section{A. Professional Response Time of Caregivers (PPA) to Outpatients at the Internal Medicine Poly Kartini Hospital, Mojokerto Regency}

Based on table 1, it is known that most respondents, as many as 108 (96.4\%), rated the response time in the fast category.

Waiting time is the time used by patients to get health services from the registration point to entering the doctor's examination room. Patient waiting time is one component that has the potential to cause dissatisfaction. The length of patient waiting time reflects how the hospital manages the service components that are tailored to the situation and patient's expectations (Depkes RI, 2010).

The category of distance between waiting time and examination time that is estimated to be satisfactory or unsatisfactory for the patient includes when the patient arrives, starting from registering at the counter, queuing and waiting for a call to the general polyclinic to be analyzed and examined by a doctor, nurse or midwife for more than 90 minutes ( old category), 30-60 minutes (moderate category) and $\leq 30$ minutes (fast category). Waiting times in Indonesia are determined by the Ministry of Health (Kemenkes) through minimum service standards. Every hospital or health center or hospital must follow the minimum service standards regarding this waiting time. The minimum standard of outpatient services based on the Ministry of Health Number 129 / Menkes / SK / II / 2008 is less or equal to 60 minutes (Ministry of Health, 2013).

Waiting time is the time it takes from a patient to register until being served by a doctor. The standard of outpatient waiting time is <60 minutes (Trenggalek Regent Regulation No.74 th. 2015).

Based on the aforementioned opinions, it can be concluded that the Response Time is a service standard that must be owned by a health service. Researchers also concluded 
that the Response Time is an element of Responsiveness which is one of the factors of patient satisfaction at the Health Center or Hospital.

\section{B. Quality of Professional Care Providers (PPA) for Outpatients at the Internal Medicine Poly Kartini Hospital, Mojokerto Regency}

Based on table 1, it is known that most of the respondents thought that the service quality was in good category as many as 89 respondents $(79.5 \%)$.

Quality is something that is decided by the customer. Quality is based on the customer's or consumers' actual experience of the product or service as measured by these requirements (Mongkaren, 2013). Service quality can be interpreted as an effort to fulfill the needs and desires of consumers and the accuracy of their delivery in balancing consumer expectations (Amrizal, 2014).

Service quality can be identified by comparing consumers' perceptions of the service they receive with the service they actually expect for the service attributes of a company. Service quality is perceived as good and satisfying if the service received or perceived (perceived service) is as expected, if the service received exceeds consumer expectations, then the service quality is perceived to be very good and quality. The quality of service is perceived as bad if the service received is lower than expected (Amrizal, 2014). The quality of health services refers to the level of perfection in the appearance of health services that can satisfy every user of health services in accordance with the average level of satisfaction of the population, the procedures for its implementation are in accordance with established standards and professional code of ethics.

People as consumers certainly want quality service. Service quality is defined as the level of excellence expected and control over that level of excellence to fulfill customer desires (Tjiptono, 2008, in Dimas and Oktafani, 2014). Service quality can be interpreted as an effort to meet the needs and desires of consumers and the accuracy of its delivery in balancing consumer expectations (Dimas and Oktafani, 2014).

One of the services that is widely used by the community is health services. According to Azwar (2014) the use of health services is the use of service facilities provided in the form of outpatient care, inpatient care, home visits by health workers or other forms of activities using these services which are based on the availability and continuity of services, community acceptance and fairness, easy achieved by the community, affordable and of good quality.

Based on the aforementioned opinions, it can be concluded that service quality is an important key which is one of the factors of patient satisfaction at the hospital.

\section{Satisfaction of Outpatients at the Internal Medicine Poly Kartini Hospital, Mojokerto Regency}

Based on table 1, it is known that almost all respondents thought that satisfaction in the service was in the satisfied category as many as 106 respondents (94.6\%).

Understanding the patient's needs and wants is an important thing that affects patient satisfaction. Satisfied patients are a very valuable asset because if patients are satisfied they will continue to use the services of their choice, but if patients are dissatisfied they will tell others twice as much about their bad experiences. To create patient satisfaction, the organization must create and manage a system to obtain more patients and the ability to retain patients. 
Patients are sick people who are treated by doctors and other health workers at the practice (Yuwono, 2013). Meanwhile, satisfaction is a person's happy feeling that comes from a comparison between pleasure in an activity and a product with expectations (Nursalam, 2011). Kotler (in Nursalam, 2011) states that satisfaction is a feeling of happiness or disappointment for someone who comes after comparing their perceptions or impressions of the performance or results of a product and their expectations. Westbrook \& Reilly (in Tjiptono, 2014) argue that customer satisfaction is an emotional response to experiences related to certain products or services purchased, retail outlets, or even behavior patterns (such as shopping behavior and buyer behavior), as well as the market as a whole. According to Yamit (2012), customer satisfaction is the result (outcome) that is felt for the use of products and services, equal to or exceeding the desired expectations. Meanwhile, Pohan (2014) states that patient satisfaction is the level of patient feelings that arise as a result of the health service performance he gets, after the patient compares with what he expects. Another opinion from Endang (in Mamik, 2010) that patient satisfaction is an evaluation or assessment after using a service, that the service chosen at least meets or exceeds expectations.

Based on the descriptions of several experts above, it can be concluded that patient satisfaction is the result of an assessment in the form of an emotional response (feelings of pleasure and satisfaction) to the patient because of the fulfillment of expectations or desires in using and receiving nurse services.

\section{Relationship Between Response Time and Quality of Caregiver Professional Service (PPA) with Satisfaction of Outpatients at the Internal Medicine Poly Kartini Hospital, Mojokerto Regency}

The results of the chi square test analysis between the response time variable and service satisfaction obtained a p-value of $0.000<\alpha=0.05$, so H0 is rejected and H1 is accepted, meaning that there is a relationship between Response Time and Satisfaction of Outpatient Patients at the Internal Medicine Poly Kartini Hospital, Mojokerto Regency.

The results of the chi square test analysis between quality variables and service satisfaction obtained a p-value of $0.008<0.05$, so $\mathrm{H} 0$ is rejected and $\mathrm{H} 1$ is accepted, meaning that there is a relationship between the quality of health care workers and satisfaction in outpatients at the Internal Medicine Poly Kartini Hospital, Mojokerto Regency.

Based on the results of the Ordinal Regression Test analysis, it shows that the variable that most influences patient satisfaction is the variable service quality with a pvalue of $0.013<0.05$, so $\mathrm{H} 0$ is rejected and $\mathrm{H} 1$ is accepted, so it can be concluded that there is a significant relationship between the quality of health care workers and satisfaction. In Outpatients at the Internal Medicine Poly Kartini Hospital, Mojokerto Regency.

One patient satisfaction is thought to be influenced by the waiting time for services. Service waiting time is a problem that often causes patient complaints in several hospitals. The length of patient waiting time reflects how the hospital manages the service components that are tailored to the patient's situation and expectations. Good and quality service is reflected in friendly, fast, comfortable service (Utami, 2015). Service company or service, customer expectations and satisfaction is influenced by customer waiting time for service. This satisfaction will in turn determine the actions of customers in their future 
purchases. Through (pre-process wait), waiting can occur before the service process begins (in-process wait), service companies must be creative and to and try to find various breakthroughs so that customers waiting to be served still feel comfortable. The impact of waiting time on customer satisfaction shows that customer satisfaction is not only influenced by the length of waiting time, but also by customer expectations in the waiting time and the cause of the length of waiting.

\section{CONCLUSIONS}

1. Of the 112 respondents, it is known that 108 respondents $(96.4 \%)$ rated the response time in the fast category.

2. Of the 112 respondents, it is known that most of the respondents thought that the service quality was in the good category as many as 89 respondents $(79.5 \%)$.

3. Of the 112 respondents, it is known that almost all respondents thought that the satisfaction in the service was in the satisfied category as many as 106 respondents (94.6\%).

4. Based on the results of the Ordinal Regression Test analysis, it shows that the variable that most influences patient satisfaction is the variable of service quality with a p-value of $0.013<0.05$, so H0 is rejected and H1 is accepted, so it can be concluded that there is a significant relationship between the service quality of health workers. With Satisfaction On Outpatients at the Internal Medicine Poly Kartini Hospital, Mojokerto Regency.

\section{ACKNOWLEDGMENTS}

The author is thankful for respondents for their valuable information and its awareness to participate in this research.

\section{CONFLICTS OF INTEREST}

The author declares that they have no conflict of interest

\section{REFERENCE}

Arini Indriyasari, (2017), Analisis Faktor Tunggu Pasien Keluar Rumah Sakit Di RSUD Dr. Iskak Tulungagung, (Tesis), Kediri: Stikes Surya Mitra Husada

Bustami, Ms (2011). Penjaminan Mutu Pelayanan, Jakarta: Penerbit Erlangga

Depkes RI, (2008). Keputusan Menteri Kesehatan Republik Indonesia No 129 Mengenai Standart Pelayanan Minimal

Menpan RI, (2017) Peraturan Menteri Pendayagunaan Aparatur Negara Dan Reformasi Birokrasi Repuplik Indonesia No. 14 Tentang Pedoman Penyusunan Survei Kepuasan Masyarakat Unit Penyelenggara Pelayanan Publik

Notoatmojo, Soekidjo, (2009). Pengembangan Sumber Daya Manusia, Jakarta: Penerbit: Rineka Cipta

Notoatmodjo, Soekidjo (2010) Metode penelitian kesehatan. Jakarta: Penerbit : PT Rineka Cipta

Nursalam, (2011), Konsep \& Penerapan Metodologi Penelitian Ilmu Keperawatan, Jakarta, Penerbit Salemba merdeka. 
Hermanto, 2010. Pengaruh Persepsi Mutu Pelayanan Kebidanan terhadap Kepuasan Pasien Rawat Inap Kebidanan Di RSUD Dr. H.Soemarnososroatmodjo Bulungan Kalimantan Timur (Tesis) : Semarang : Universitas Diponegoro

Rahmat Surya N, (2017) Kepuasan Pasien Rawat Inap Ditinjau dari Manajemen Sumber Daya Manusia Di RS Muhamadiyah Ahmad Dahlan Kota Kediri (tesis) : Kediri: Stikes Surya Mitra Husada

Susatyo, Herlambang (2012), Manajemen Rumah Sakit, Sleman Yogyakarta: Penerbit Gosyen.

Wilde Larson (2010) Pengukuran Tingkat Kepuasan Pelangan. Jakarta: Salemba

Arini Indirayasari (2017) Analisis Faktor Tunggu Pasien Keluar Rumah Sakit Di RSUD DR. ISKAK Tulungagung (Tesis) : Kediri: Stikes Surya Mitra Husada. 